\title{
SISTEM DRAINASE DI KORIDOR JAMIN GINTING PANCUR BATU SUMATERA UTARA
}

\author{
Nanda Hafiz Pratama Lubis ${ }^{1}$, Beny O.Y Marpaung ${ }^{2}$ \\ ${ }^{1,2}$ Program Studi Magister Teknik Arsitektur Fakultas Teknik Universitas Sumatera Utara \\ Jl. Perpustakaan St. J07 Building, Medan, 20155, Indonesia \\ *Email: ${ }^{1}$ nandahafizpratama@gmail.com, ${ }^{2}$ beny.marpaung@usu.ac.id
}

\begin{abstract}
ABSTRAK
Sistem Drainase Perkotaan merupakan salah satu komponen prasarana perkotaan yang sangat erat kaitannya dengan penataan ruang. Bencana banjir yang sering melanda sebagian besar wilayah dan kota di Indonesia disebabkan oleh kesemrawutan penataan ruang. Pengelolaan air kotor belum dilakukan dengan benar serta belum terdapatnya menajemen koridor tentang air kotor dan peraturan dalam pengelolaan lingkungan koridor dan pengelola untuk air kotor koridor. Saluran drainase pada koridor jalan Jamin Ginting tidak dirancang dengan baik sehingga dapat membahayakan pengguna jalan, khususnya di bangunan Cina Melayu pengguna jalan harus melewati drainase yang tidak tertutup dan terdapat juga bangunan liar diatas saluran drainase. Sistem jaringan air kotor dilokasi Koridor Jamin Ginting Pancur Batu ini tidak cukup bersahabat pada masyarakat. Banyak saluran drainase yang tidak sesuai diperuntukkan kondisi lingkungan yang terdapat pada saluran yaitu terdapat sampah dan kondisi diatas saluran terdapat bangunan dan ruko yang menutupi saluran sehingga membuat air kotor tidak mengalir sempurna. Terdapat juga titik pembuangan saluran yang tidak sesuai dengan titik elevasi terendah sehingga banyak genangan disekitar saluran.
\end{abstract}

Kata Kunci: Saluran Drainase.

\section{PENDAHULUAN}

Drainase berasal dari bahasa Inggris "drainage" yang mempunyai arti mengalirkan, menguras, membuang, atau mengalihkan air. Secara umum, sistem drainase dapat didefinisikan sebagai serangkaian bangunan air yang berfungsi untuk mengurangi dan atau membuang kelebihan air dari suatu kawasan atau lahan, sehingga lahan dapat difungsikan secara optimal.Sistem drainase terdiri dari saluran penerima (interceptor drain), saluran pengumpul (collector drain), saluran pembawa (conveyor drain), saluran induk (main drain) dan bagian penerima air (receiving waters).

Pada dasarnya sistem drainase yang tidak termanajemen maksimal sehingga mengakibatkan banjir. Banjir merupakan kata yang sangat popular di Indonesia, khususnya musim hujan. Peristiwa ini hampir setiap tahun berulang, namun perma salahan ini sampai saat ini belum terselesaikan, bahkan cenderung

Makin meningkat, baik frekuensinya, luasannya, kedalamannya, maupun durasinya.
Akar permasalahan banjir di perkotaan berawal daripertambahan penduduk yang sangat cepat, diatasrata-rata pertumbuhan nasional, akibat urbanisasi, baik migrasi musiman maupun permanen. Pertambahan penduduk yang tidak diimbangi dengan penyediaan prasarana dan sarana perkotaan yang memadai mengakibatkan pemanfaatan lahan perkotaan menjadi acakacakan (semrawut). Pemanfaatan lahan yang tidak tertib inilah yang menyebabkan persoalan drainase di perkotaan menjadi sangat kompleks.

Sistem Drainase Perkotaan merupakan salah satu komponen prasarana perkotaan yang sangat erat kaitannya dengan penataan ruang.Bencana banjir yang sering melanda sebagian besar wilayah dan kota di Indonesia disebabkan oleh kesemrawutan penataan ruang. Sistem drainase yang buruk menjadi penyebab utama banjir di Kecamatan Pancur Batu. Sebagian besar disebabkan karena saluran air tidak ada, saluran tersumbat sampah, dan akibat bangunanyang mengganggu saluran. 


\section{Debit Air Limbah Buangan (Air Kotor)}

Debit Air Limbah Buangan adalah semua cairan yang dibuang, baik yang mengandung kotoran manusia maupun yang mengandung sisa-sisa proses industri. Air Buangan dapat dibagi menjadi 4 golongan, yaitu:

1. Air Kotor: Air buangan yang berasal dari kloset, peturasan, bidet dan air buangan yangmengandung kotoran manusia yang berasal dari alat-alat plambing.

2. Air Bekas: Air buangan yang berasal dari alat-alat plambing lainnya seperti bak mandi, baik cuci tangan, bak dapur dan lain-lain.

3. Air Hujan: Air buangan yang berasal dari atap bangunan, halaman dan sebagainya.

4. Air Buangan Khusus: Air buangan yang mengandung gas, racun atau bahanbahan berbahaya seperti berasal dari pabrik, air buangan laboratorium, tempat pengobatan,tempat pemeriksaan di rumah sakit, rumah pemotongan hewan, air buangan yang bersifat radioaktif yang dibuang dari pusat Listrik Tenaga Nuklir.

Analisa pada System Drainase untuk mengetahui daerah yang tergenang dan pengaruhnya pada tata guna lahan, sarana dan prasarana pada koridor. Dengan memanfaatkan sistem drainase perkotaan yang berkelanjutan secara optimal akan mempercepat pengambilan keputusan dalam upaya penanggulangan banjir yang terprogram dan terencana.

\section{TINJAUAN PUSTAKA}

Drainase diartikan sebagai usaha untuk mengontrol kualitas air tanah dalam kaitannya dengan salinitas. Jadi, drainase menyangkut tidak hanya air permukaan tapi juga air tanah (Suripin, 2004).

\section{Sistem Drainase}

Secara umum, sistem drainase dapat didefinisikan sebagai serangkaian bangunan air yang berfungsi untuk mengurangi dan/atau membuang kelebihan air dari suatu kawasan atau lahan, sehingga lahan dapat difungsikan secara optimal.Bangunan sistem drainase terdiri dari saluran penerima (interceptor drain), saluran pengumpul (collector drain), saluran penerima (conveyor drain), saluran induk (main drain) dan badan air penerima (receiving waters). Disepanjang sistem sering dijumpai bangunan lainnya seperti gorong-gorong, siphon,jembatan air (aquaduct), pelimpah, pintupintuair, bangunan terjun, kolam tando, dan stasiunpompa (Suripin, 2004).

Drainase perkotaan adalah ilmu yang diterapkan mengkhususkan pengkajian pada kawasan perkotaan yang erat kaitannya dengan kondisi lingkungan sosial yang ada di kawasan kota. Drainase perkotaan/terapan merupakan sistem pengiringan dan pengaliran air dari wilayah perkotaan yang meliputi: (1) Pemukiman; (2) Kawasan Industri; (3) Kampus dan Sekolah; (4) Rumah Sakit dan Fasilitas Umum; (5) Lapangan Olahraga; (6) Lapangan Parkir; (7)Pelabuhan Udara.

Kriteria desain drainase perkotaan memiliki kekhususan, sebab untuk perkotaan ada tambahan variabel desain seperti: (1) Keterkaitan dengan tata guna lahan; (2) Keterkaitan dengan masterplan drainasi kota; (3) Keterkaitan dengan masalah sosial budaya (H.A. Halim Hasmar: 2012).

\section{METODE PENELITIAN}

Penelitian ini menggunakan metode analisis deskriptif kualitatif, dimana metode studi yang digunakan adalah metode sistematis perencanaan yang meliputi 5 (lima) tahap, yaitu: (1) Persiapan; (2) Inventarisasi; (3) Analisis; (4) Sintesis; (5) Perencanaan (Gold, 1980). Sesuai dengan karakter saluran maka dilakukan dengan pendekatan fisik yaitu menentukan tipe-tipe serta kemungkinan-kemungkinan saluran berdasarkan kondisi fisik saluran yang ada dan potensial di saluran Pancur Batu berdasarkan standart.

\section{HASIL DAN PEMBAHASAN}

Untuk menghasilkan konsep penataan saluran berdasarkan fungsi dari drainase perkotaan Pancur Batu, terlebih dahulu peneliti mendeskripsikan kondisi eksisting serta kajian mengenai pengembangan saluran drainase 


\section{Kondisi Fisik}

Kecamatan Pancur Batu memiliki luas $122.53 \mathrm{~km}^{2}$ merupakan salah satu kecamatan dari 30 kecamatan yang ada di Kabupaten Deli Serdang sejak tahun 1952, oleh Gubernur Abdul Hakim yang mengadakan perubahan tingkat I Sumatera Utara. Sebelum tahun 1945, koridor Jalan Jamin Ginting memang dipergunakan masyarakat sebagai kawasan perdagangan dan jasa.

Peneliti meneliti Saluran drainase Perkotaan Pancur Batu terletak pada 3,2 Km dimulai dari perbatasan antara Medan dan Deli Serdang. Saluran yang berbatasan langsung dengan saluruan kota medan ini cukup memprihatinkan dikarenakan saluran yang berada pada bawah bangunan. Dan saluran juga tidak terawat dengan baik (Gambar 1).

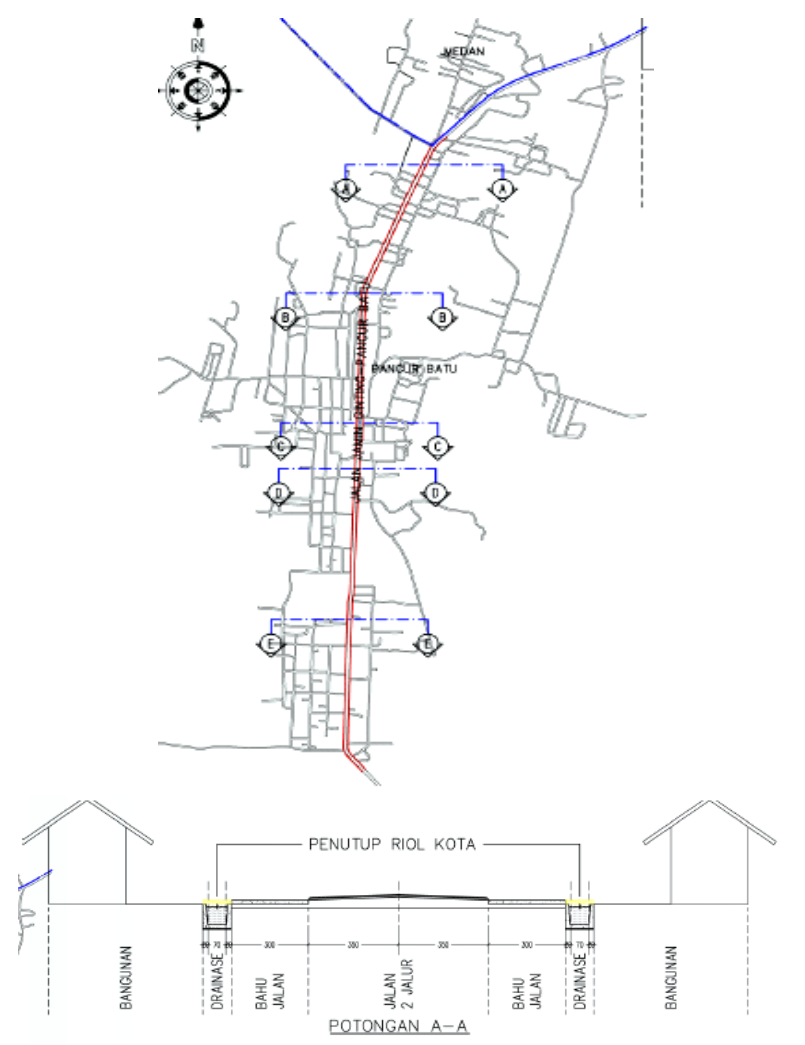

Keterangan gambar:

Pot A-A (Perbatasan Medan dengan Deli Serdang)

Gambar 1. Peta kawasan Koridor Pancur Batu

Kawasan ini merupakan salah satu dari 5 (lima) segmen saluran yang ada di Pancur Batu, sepanjang $3,2 \mathrm{Km}$ potongan saluran memiliki dimensi yang sama dengan perbedaan ruas jalan disepanjang koridor tersebut (Gambar 2).

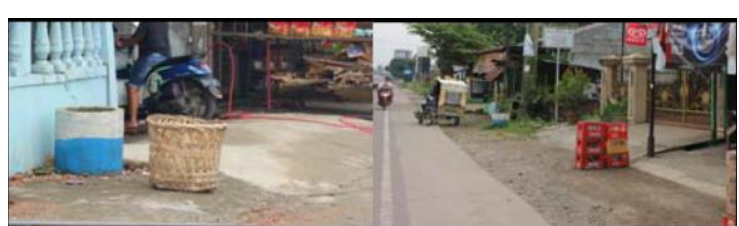

Gambar 2. Suasana saluraan drainase kawasan Pancur Batu

Saluran drainase ini memiliki dimensi lebar atas $70 \mathrm{~cm}$, lebar bawah $50 \mathrm{~cm}$. Terdapat bangunan yang berada di atas saluran sehingga membuat air hujan yang turun tidak masuk sempurna ke dalam saluran.

Pancur Batu memiliki sejumlah besar curah hujan sepanjang tahunnya. Hal ini berlaku bahkan untuk bulan terkering. Bulan terkering adalah Juni, dengan $152 \mathrm{~mm}$ hujan. Rata-rata $350 \mathrm{~mm}$, hampir semua presipitasi jatuh pada April. Bulan terhangat sepanjang tahun adalah Mei, dengan suhu rata-rata $26.1^{\circ} \mathrm{C}$. Oktober memiliki suhu rata-rata terendah dalam setahun, $25.2^{\circ} \mathrm{C}$. Kondisi ini sangat berpengaruh bagi saluran drainase daearah Pancur batu. Selain dari pembuangan rumah warga sehingga membuat genangan sekitar ruas jalan.

\section{$\underline{\text { Kondisi sosial }}$}

Pengunjung pada pasar Pancur Batu yang sebagian besarnya terdiri dari masyarakat sekitar yang sudah berumur tua dan masyarakat yang membawa anak dalam kunjungan ke pasar. Drainase yang membahayakan bagi kegiatan yang dilakukan oleh pengunjung dipasar yang bersifat untuk kebutuhan pokok rumah tangga sangat membahayakan bagi pengunjung dikarenakan sistem drainase yang tidak teratur dan tidak bersahabat bagi masyarakat dikarenakan sistem saluran drainase yang terbuka pada koridor khususnya didepan daerah pertokoan yang relatif dekat dengan jalur pedestrian dengan saluran (Gambar 3).

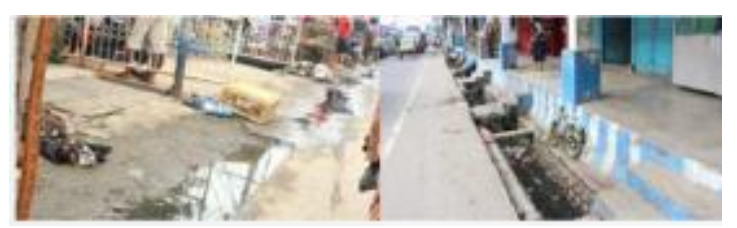

Gambar 3. Suasana saluran drainase kawasan Pasar Pancur Batu

Kegiatan sehari-hari sebagian besar merupakan kegiatan yang dilakukan masyarakat sekitar Pancur Batu yang bersifat berbelanja. 
Analisa kesesuaian fisik yang ada pada drainase dengan dikembangkan upaya untuk mengetahui dapat atau tidaknya saluran drainase untuk menampung sistem air kotor di daerah Pancur Batu. Baik dalam sistem curah hujan maunpun air kotor yang dikeluarkan oleh masyarakat pancur batu. Dengan adanya eksisting saluran drainase di Lokasi Pancur batu agar dapat menampung debit keselurahan mulai dari curah hujan dan limbah yang dihasilkan.

\section{Konsep}

\section{Konsep perencanaan}

Konsep dasar studi perencanaan ini adalah penataan berdasarkan kepada fungsi saluran drainase . Hal tersebut dijabarkan dalam bentuk yang dikembangkan serta penataan saluran drainase. Konsep perencanaan saluran merupakan pengembangan pemanfaatan potensi saluran, pemecahan masalah atau hambatan serta disesuaikan dengan kebutuhan saluran yang ada. Konsep ini pada prinsipnya merupakan pengembangan fungsi-fungsi saluran yang adai di Kecamatan Pancur Batu. Untuk mengakomodasikan fungsi-fungsi diatas terhadap konsep yang terdiri dari konsep saluran drainase yang baik bagi masyarakat.

\section{Konsep saluran drainase}

Konsep drainase pada Kecamatan Pancur Batu Khususnya pada Koridor tersebut yang berada di atas permukaan tanah yang berfungsi mengalirkan air limpasan permukaan sebaiknya dengan kemiringan yang akurat sehingga aliran air tidak berhenti dan sampai ke pembuangan akhirnya (Gambar 4).
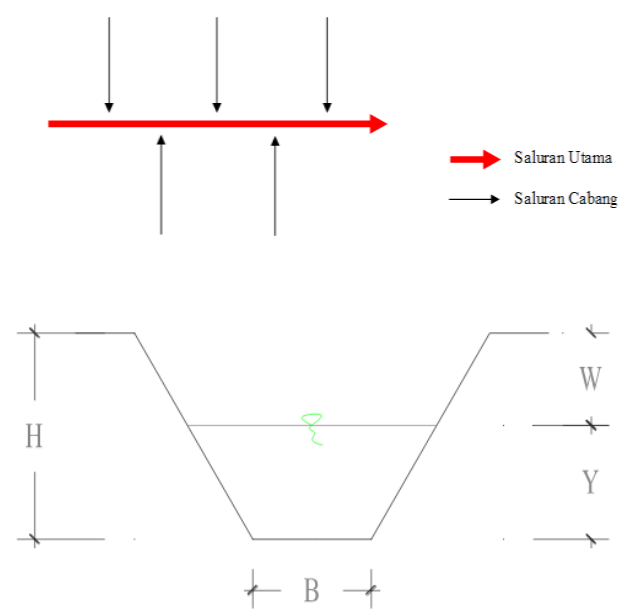

Gambar 4. Konsep penataan saluran drainase di Pancur Batu
Pada umumnya saluran ini terbuat dari tanah akan tetapi tidak menutup kemungkinan dibuat dari pasangan batu dan beton. Saluran ini memerlukan cukup ruang. Berfungsi untuk menampung dan menyalurkan limpasan air hujan serta air buangan domestik dengan debit yang besar.

Konsep saluran pada jalan raya yang ramah bagi masyarakat dan tidak mengakibatkan masyarakat terjatuh dikarenakan saluran yang terbuka dan dekat dengan aktivitas masyarakat khususnya pada pasar (Gambar 5).

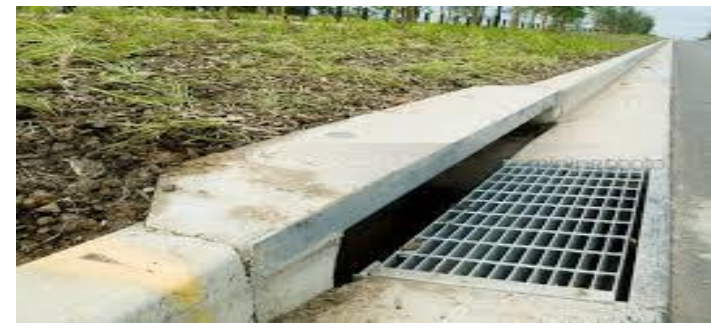

Gambar 5. Konsep drainase pada jalan raya dekat dengan pasar

Konsep saluran drainase yang terletak di Potongan A-A pada Koridor Kecamatan Pancur Batu yang memiliki ruas jalan yang besar dan didukung dengan trotoar yang lebar maka dibuat sistem saluran terbuka dengan sistem vegetasi didekat saluran. Potongan A-A Dan B-B memiliki trotoar yang lebar sehingga konsep penaataan saluran (Gambar 6).

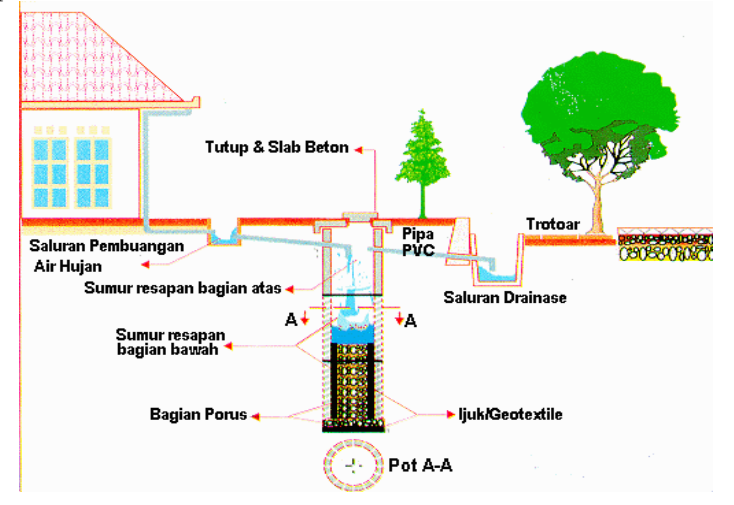

Gambar 6. Konsep Saluran drainase pada segmen I atau Potongan A-A

Konsep pada potongan C-C dan D-D pada gambar I dibuat sistem saluran drainase tertutup plat beton dan dibuat sistem penyaringan untuk sampah yang akan terikut oleh aliran air melalui air (Gambar 7). 


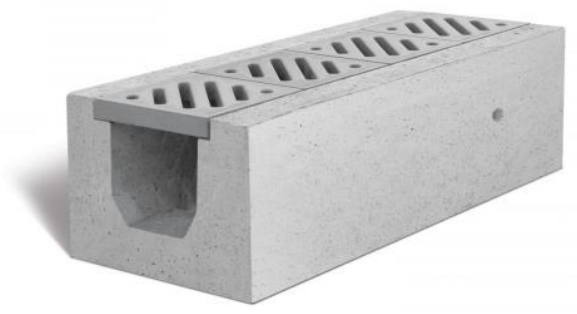

Gambar 8. Konsep saluran drainase tertutup

Konsep pada saluran tertutup seperti gambar dibawah ini juga dapat digunakan pada lokasi pada C-C dan D-D.

\section{KESIMPULAN}

Hasil rencana pembangunan saluran drainase pada Koridor Jamin Ginting Kecamatan Pancur Batu pada sauran berbentuk saluran tertutup dan terbuka dengan sistem kemiringan yang sesuai stadarisasi yang ada dalam peraturan SNI dalam rama lingkungan dengan sistem yang bershabat bagi masyarakat dan tidak mengalami kebanjiran akibat air kotor yang dipengaruhi pada limbah masyarakat maupun curah hujan yang ada.

\section{Daftar Pustaka}

Burrough,P.A (1994) Principles of Geographical Information System for Land Resource Assessment. Oxford University Press Inc., New York

Carr, Stephen, et.al. (1922) Public Space, Cambridge University Press, Cambridge.

ESRI (1996) Arc View GIS: Installation Guide, Environmental Systems Research Institute, Inc.

https://katailmu.com/2013/02/jenis-jenis saluran.htm

https://wikipedia.com
JICA (1992) The Master Plan on Water resources Development and Feasibility Study for Urgent Flood Control and Urban Drainage in Semarang City and Suburbs. Inten Report I.

Nelson Prof., S.A. (2003) Streams and Drainage Systems, Tulane University, http://www.tulane.edu/ sanelson/ge ol111/ streams.htm.

Suripin Dr. Ir. M.Eng (2004) Sistem Drainase Perkotaan yang Berkelanjutan, Andi Offset, Yogyakarta 